\title{
A boycott of tobacco-sponsored cars?
}

Marlboro, Camel, Gitanes, Lucky Strike, and Rothmans each sponsor international Grand Prix motor racing (Formula 1 cars or motorcycles). Other brands sponsor racing in Indycar and other regional and national race events. The world over, only the most isolated nomad or villager could avoid at least some exposure to the scores of annual televised races and to the associated promotions (advertising, clothing, bumper stickers, and so on) that massively extend coverage of these unregulated orgies of tobacco advertising. For hundreds of millions of racing fans, particularly young men, the apposition of tobacco advertising with these thrilling icons of power, excitement, speed, glamour, and success makes an unequivocal statement that is peerless in both volume and reach: cigarette smoking is all these things too.

If the racing teams and car manufacturers which accepted this tobacco sponsorship all refused to do so, these incomparable advertising opportunities would be denied to the tobacco companies. In allowing their vehicles to carry this advertising, car manufacturers such as Honda and Renault and motorcycle manufacturers Honda, Yamaha, and Suzuki collude with the marketing ambitions of their tobacco sponsors. Their vehicles carry persuasive endorsements for the use of a product that will kill an estimated 10 million people a year by the year $2020^{1}$. Yet to date, the ethics of this collusion have passed almost wholly unremarked in the world's health and medical communities.

Since publication of the first Royal College of Physicians of London's report on smoking and health in 1962, the medical and allied public health professions have taken a lead in tobacco control. In most countries, doctors are one of the more affluent occupational groups and among their purchases are cars worth billions of dollars. Worldwide, doctors' aggregated purchasing of those makes of cars that currently agree to carry tobacco advertising would certainly be prodigious. Any significant loss of such a sales volume would give these manufacturers great pause to consider the wisdom of continuing the association.

We are interested in starting a discussion about how to plan a worldwide movement that would encourage doctors and health workers to threaten to boycott the purchase of vehicles which carry tobacco advertising, until such time that these companies reject all sponsorship by tobacco companies. An international boycott would be guaranteed to attract significant publicity, which in turn would be likely to draw many thousands of sympathetic consumers into the boycott.

We are proposing to convene a meeting of representatives of medical and health associations from around the world at the 9th World Conference on Tobacco and Health in Paris in October 1994 to plan strategy to implement this proposal. We will also be placing the proposal before the World Medical Council later this year. We would be pleased to hear from associations and individuals in any country who would like to begin to plan this boycott campaign prior to its launch. Please address all correspondence to the first author at the address below.

$$
\begin{array}{r}
\text { SIMON CHAPMAN } \\
\text { Vice President, Public Health Association of Australia } \\
\text { Department of Community Medicine } \\
\text { Westmead Hospital, Westmead 2145 Australia } \\
\text { ALEX COHEN } \\
\text { Mresident, Royal Australasian College of Physicians } \\
\text { Macquarie St } \\
\text { Sydney } 2000 \text { Australia } \\
\text { BRENDON NELSON } \\
\text { President, Australian Medical Association } \\
\text { Canberra 2600 Australia } \\
\text { STEPHEN WOODWARD } \\
\text { Executive Director, Action on Smoking and Health } \\
\text { Dowling Street } \\
\text { Woolloomooloo 2011 Australia }
\end{array}
$$

1 Peto R Lopez AD Worldwide mortality from current smoking patterns. In Durston B, Jacrozik K. Tobacco and Health 1990: The Global War. Proceedings of the Seventh World Conference on Tobacco and Health, Perth, Western Australia, 1-5 April 1990: 66-8. 